\title{
Reviewing the Hedge Funds Literature II: Hedge Funds' Returns and
}

\section{Risk Management Characteristics}

Izidin El Kalak ${ }^{1 *}$, Alcino Azevedo**, Robert Hudson**

*Kent University Business School

**Hull University Business School

\begin{abstract}
This paper summarizes the literature on hedge funds (HFs) developed over the last two decades, particularly that which relates to risk management characteristics (a companion piece investigates the managerial characteristics of HFs). It discusses the successes and the shortfalls to date in developing more sophisticated risk management frameworks and tools to measure and monitor HF risks, and the empirical evidence on the role of the HFs and their investment behaviour and risk management practices on the stability of the financial system. It also classifies the HF literature considering the most recent contributions and, particularly, the regulatory developments after the 2007 financial crisis.
\end{abstract}

\section{JEL Classification Code:}

Keywords: Hedge Funds; Return characteristics, Risk management characteristics.

\footnotetext{
${ }^{1}$ Corresponding Author: i.el-kalak@kent.ac.uk.
} 


\section{Introduction}

Hedge Funds (HFs) are investment pools that raise capital from large institutions and wealthy investors but not from the general public. HFs are a dynamic part of the world's financial system and develop and use some of the most innovative investment and risk management strategies with the goal of mitigating risk and enhancing returns performance. On the other hand, HFs are very active players in the financial derivatives market which stimulates market liquidity and facilitates the flow of capital. Despite these benefits, HFs are also often regarded as major contributors to financial instability and as taking unjustified benefits from the lack of regulations and transparency in the financial markets, as well as for being dangerously leveraged and too engaged in short selling.

Hedge fund managers (HFM) and investors, as well as financial regulators, should, therefore, understand the relationship between HF returns and the characteristics that enable them to generate absolute returns in excess of other traditional investment vehicles.

This paper reviews the HF literature focused on the HF returns and the related risk management strategies. It also classifies the literature considering the most recent contributions and the regulatory developments after the 2007 financial crisis and suggests new avenues for research considering the critical problems which have not yet been adequately addressed.

This paper is organized as follows. In the next section, we identify and categorize the HF return characteristics. In section 3 we review an extensive number of articles focused on the HF industry's risk management characteristics and developments in their risk management behaviour patterns that have occurred in the last two decades. In section 4 we conclude.

\section{HF returns characteristics}

\subsection{HF returns components and market neutrality}

HF returns can be classified into two main components: Beta and Alpha. Beta is an indicator of the volatility of the returns generated from the exposure to different asset classes, whereas alpha represents the return generated as a consequence of the manager's skill. These concepts are used to classify the investment strategies of HFs and to benchmark HF performance. In the literature, both linear single and multi-factor models are used to determine the alpha and the beta of HFs, where alpha is the intercept term of the regression and betas are the regression coefficients.

HFs were initially created to reduce market risk by hedging their exposure using a combination of long and short positions on the assets held. Under such circumstances, the correlation between beta and the market is low or inexistent. This idea, known as "market neutrality" was studied by Liang (1999) using an eight-asset class factor model, who found that HFs were relatively less correlated with the traditional asset classes (such as stocks and bonds) than mutual funds, which tend to be highly correlated to market 
indices such as the S\&P500. Patton (2009) classifies market neutrality according to four types: mean, variance, value at risk and tail neutrality and like Liang (1999) also concludes that "most HFs which are classified as market neutral are not really market neutral".

Building on the Pastor and Stambaugh (2009) finding that serially correlated residuals from predictive regression modelling on different HF style portfolios suggest imperfect predictors, Cai and Liang (2012) proposed a dynamic linear regression model that could reduce the autocorrelation of the residuals and conclude that HFs classified as market neutral are close to a neutral exposure and demonstrate better neutrality when compared to riskier equity management styles. Sharpe (1992) proposes a style analysis model which includes a linear asset class factor for analyzing mutual funds' (MFs) styles, where the style analysis is considered as a special case of the linear multi-factor model. Fung and Hsieh (1997) extend Sharpe's (1992) model and provide an integrated framework very useful to analyze and classify the main components of each HF's returns according to their strategy type. More specifically, they decompose funds' return into three components related to where the fund trades (asset class), how the fund trades (strategy) and how much the fund trades (leverage). They model HF styles using linear combinations of rule-based trading strategies using information from a dataset which comprises information on 409 HFs over the time period of 1993 to 1995. By using factor analysis, the authors classify five mutually orthogonal principle components: global macro, system traders, system/opportunistic, value style, and distress style.

Brown and Goetzmann (2001) analyze the different HF styles based on a method which is an extension of k-mean cluster analysis (i.e. hard and fuzzy clustering) and finds that there are at least eight distinct styles used by HFs, where each is associated with a different risk exposure. Bares et al. (2001) use a similar methodology and study, among other things, the style consistency of the asset allocation strategies. Maillet and Rousset (2003) proposed a theoretical model which utilises the Kohonen classification mapping using an algorithmic approach that allows the characterization of the families of funds according to their conditional densities.

\section{$<$ Insert Table 1 $>$}

\subsection{Nonlinearity of returns}

The dynamic use of long and short positions in HFs generates a nonlinear relationship between the market returns and the HF returns. This raises doubts about the suitability of normal linear-factor methods for testing market neutrality. Hence, there is a need for more sophisticated methods to study neutrality and to adjust the returns to their corresponding systematic risk factors, and two main frameworks have emerged: one is named a bottom-up approach, and is used for instance by Fung and Hsieh (2001) and Mitchell and Pulvino (2001), another is a named a generalized approach, and is used for instance by Agarwal and Naik (2004) and Dor et al. (2003). 
The bottom-up approach analyzes the HFs specific strategies separately, starting with underlying conventional assets (such as stocks and bonds) to test neutrality and extract the systematic risk factors. Fung and Hsieh (2001) developed this approach, which was named asset based style (ABS). They rely on Merton (1981), where market timers can hold long positions in the market, and extend it so as to allow the trend followers ${ }^{2}$ to go long and short through the use of option-based investment strategies. They also posit that the simplest trend-following strategy (the Primitive trend-following strategy) has the same payout as the "lookbacks-straddle" option. In order to replicate the performance of the trendfollowing strategy for each market asset, they label the Primitive Trend-Follower Strategy (PTFS) for that market and show that these PTFSs capture two essential performance features of trend-following funds. First, they show that there is a nonlinear relationship between the trend of the followers' return and the trend of the equity market and confirm that trend-following funds do have a systematic risk and are, therefore, not market neutral.

Using a sample period starting in 1997, where the sample used by Fung and Hsieh (2001) ends, Fung and Hsieh (2007) provide an out of sample verification of their results, demonstrating that their 2001 model correctly predicts the return behaviour of trend-following strategies for the out of sample periods, especially during stressful market conditions such as those of September 2001. Mitchell and Pulvino (2001) use a sample of 4,750 mergers and acquisitions for the period between 1963 and 1998 to examine returns generated from risk arbitrage. ${ }^{3}$ Their results suggest that risk arbitrage returns are similar to those obtained from writing uncovered index put options. They evaluate their results on the assumption that a nonlinear relationship with market returns holds, they use a contingent claims analysis. and report that the risk arbitrage generates excess returns of around $4 \%$ per year.

Fung et al. (2002) use the ABS approach to extract the common sources of risk related to fixed-income HFs. ${ }^{4}$ This type of trading is very risky because the relative price of two assets can easily diverge. Therefore, fixed-income securities are subject to several important risks related to interest rate spreads such as convertible/treasury spread, mortgage/treasury spread, and high-yield/treasury spread, being sources of risk related to market risk factors. By identifying the ABS factors, they were able to determine that the majority of fixed-income HFs are exposed to a large increase in credit spreads. This finding has a huge impact on the asset allocation since managers are able to identify the main risk factors and therefore to select the components that increase the HF alpha.

\footnotetext{
${ }^{2}$ Trend following is a strategy commonly used by commodity (CTAs). The returns of trend-following trading advisors (funds are uncorrelated with the standard equity, bonds, currency, and commodity indices).

${ }^{3}$ Risk arbitrage is an investment strategy where managers attempt to profit from the spread between a target's stock price and offer price, after the announcement of a merger or acquisition.

${ }^{4}$ Fixed-income HFs are considered to follow convergence trading that bets on the relative prices of two assets to converge.
} 
Agarwal et al. (2011b) also use the ABS methodology to analyze the risk-return characteristics of convertible arbitrage funds. ${ }^{5}$ They theorize the existence of three "primitive trading strategies" (PTS) which can justify the convertible arbitrage fund's returns. ${ }^{6}$ Those PTSs can also be considered to be ABS factors that explain a significant proportion of the return variation of convertible arbitrage funds. Agarwal et al. (2011b) extend the work of Agarwal and Naik (2004) by studying the characteristics of the key drivers of convertible arbitrage strategies and their impact on the performance of HF. They report that the buy-and-hedge strategy representing long positions in convertible bonds while hedging the equity risk alone explains a significant amount of the return variation, and highlight the importance of non-price variables, such as extreme market-wide events and the supply of convertible bonds in affecting the HF performance.

The second approach used in analyzing the risk-return characteristics of HFs taking into consideration the nonlinear relationship between HF and market returns is known as the "generalized approach". Agarwal and Naik (2004) use buy-and-hold and option-based risk factors to characterize the nonlinear systematic risk exposures of a wide range of HF investment strategies and propose a two-step approach, where they, first, estimate the factor loadings of HFs using a multi-factor model containing returns on standard asset classes and embedded options as risk factors and, second, test how well these risk factors capture the out of sample HFs performance. Their results show that it is important to allow for nonlinear risk-return relation. Regarding the non-linear exposure to equity market index, they find that hedge funds exhibit significant risk exposures to Fama-French's (1993) size and value factors. They also find that a large number of equity-oriented hedge fund strategies exhibit payoffs resembling a short position in a put option on the market index, and therefore bear significant left-tail risk - a risk which is ignored by the commonly used mean-variance framework.

Fung and Hsieh (2004b) extend the work of Fung and Hsieh (2002) on ABS factors and propose an APT-like model of HF returns with dynamic risk factor coefficients where seven risk factors are identified, which can explain part of the systematic risk of a typical HF portfolio using conventional security prices. This approach provides a framework for measuring HF performance while taking into account both time-varying and nonlinear risk characteristics and provides a link between the conventional asset class risks and the HF risks. The authors report empirical results showing that the seven risk factors explain between $55 \%$ and $80 \%$ of the return movements of HF portfolios. ${ }^{7}$

\section{$<$ Insert Table 2>}

\footnotetext{
${ }^{5}$ The convertible arbitrage strategy attempts to exploit profits when there is a pricing error made in the conversion factor of the convertible security.

${ }^{6}$ These PTSs are: volatility arbitrage, positive carry, and credit arbitrage.

${ }^{7}$ The Seven risk factors are: two equity factors (equity market and size), two fixed-income factors (bond market and credit spread), and three trend-following factors for bond, currency, and commodity markets.
} 


\subsection{HFs' alphas and their persistency}

There is an extensive empirical literature examining the time-persistency of the HFs' alphas. For instance, Fung and Hsieh's (2004a) regress three HFs indices on the Fama-French three-factor model augmented with the momentum factor as implemented by Carhart (1997) and find evidence supporting the existence of alpha time-persistency in equity long/short HFs. Kosowski et al. (2007) use a nonparametric bootstrap methodology and show that there is annual persistency in the HF's alphas. They also find that the differences between the best and the worst funds alphas persist over time although this time-persistency is difficult to replicate given that the HFs positioned at the top are often small and closed to new investments. In addition, to mitigate the short sample problem they use a Bayesian approach which leads to superior performance predictability. They show that sorting on Bayesian alpha compared to sorting on ordinary least square (OLS) alpha yields a 5.5\% per year increase in the Bayesian alphas compared to their OLS alphas.

Fung et al. (2005) show that alphas play a major role in determining the quality of funds of hedge funds (FoHFs). They show that funds having significant and positive alphas (HAVE group) have less survivorship risk $^{8}$ and take smaller beta bets than those that do not have significant and positive alphas (HAVE-NOT group) and that the alphas vary over time. More specifically, they divide the sample into three sub-samples ${ }^{9}$ and find that the (HAVE) group exhibit a statistically significant alpha over the three periods, whereas the (HAVE-NOT) group only deliver significant alpha during the second period. However, for the (HAVE) alpha group they show a declining trend of alpha from the first to the third periods, raising the question of what is really affecting alpha. To answer this question they analyze the supply of alpha using style analysis for each fund in line with Sharpe (1992) and Fung and Hsieh (1997). They find that the supply of alphas is cyclical depending on both market environment and HF style.

While testing the ability of HFs to generate alpha over time, in line with the Berk and Green (2004) model, many studies, including Kosowski et al. (2007), Fung et al. (2008), and Cai and Liang (2012), report a declining trend in alpha over time, in addition to a negative effect of a fund's capital growth on its ability to generate alpha. Naik et al. (2007) investigate the reasons behind the substantial decline in alpha over the period from 1995 to 2004 and report that capacity constraints at the level of HF strategies are responsible for this decline. Fung and Hsieh (2004a) also investigate the alpha time-persistency in the equity long/short HFs. After adjusting for risk factors through the implementation of a standard four-factor model, they report that less than $20 \%$ of the sample exhibits a significant alpha over time. Their results confirm those of the Berk and Green (2004) showing a decaying alpha over time. In

\footnotetext{
${ }^{8}$ Survivorship risk occurs when poor performing funds disappear from database by ceasing to report so that only good performing funds remain to report their returns.

${ }^{9}$ Pre-LTCM (February 1994 to September 1998), Internet bubble (October 1998 to March 2000) and the most recent period (April 2000 to December 2004).
} 
addition, they provide a new insight on the main drivers of alpha, which go beyond the conventional approach and find that the long/short equity HFs depends on the preferential access to the stock loan market and the level of stock market activity (proxied by stock market volume) to deliver higher alpha and show that the lower levels of aggregate short sale interest work in enhancing the managers' ability to take more short positions that deliver higher alpha.

Some authors adopt the alternative explanation of significant and positive alphas being generated by managerial skills. In support of their argument, they relate the positive alphas to model misspecification or missing risk factors. Bondarenko (2004) finds that "variance risk" can be priced by implementing a model-free approach, and its premium risk is negative and economically very large. Linking these findings to the HF arena, Bondarenko (2004) argues that HF returns demonstrate negative exposure to the variance return ${ }^{10}$ and this exposure accounts for a large proportion of the average HF return. Hence, he provides an alternative explanation for the factors affecting alpha, arguing that this variance return is an important factor determining HF returns.

Aragon (2003) studies the liquidity effect on the superior performance of HFs and finds a positive (concave) relationship between HF returns and the restrictions imposed by private investment funds and concludes that a positive alpha can be interpreted as compensation for holding illiquid fund shares. In addition, he argues that share restrictions allow funds to efficiently manage illiquid assets, based on the negative relationship between share restrictions and the liquidity of the funds' portfolio.

According to Ackermann et al. (1999), another explanation for the superior alphas is the fact that there is no practical and cheap way to replicate dynamic trading strategies by individual investors. Therefore, investing through HFs can improve investors' utility even though they have to pay high incentive and management fees. So, the high alpha is due to the unique resources available to managers rather than their superior skills. Ackermann et al. (1999) are in favour of this argument as they find that incentive and management fees are almost equal to the HFs' ability to achieve superior gross returns.

\section{$<$ Insert Table 3>}

\subsection{Misreporting returns}

In some cases, HFs managers tend to misreport returns in order to impress investors with a good performance and, consequently, attract more cash inflows and reduce the likelihood of cash outflows during bad periods. This misreporting is also known as intentional returns smoothing. Previous studies such as Getmansky et al. (2004) document a high serial correlation in HF returns. This serial correlation creates biases in the risk-adjusted measures such as the Sharpe ratio (see Lo, 2002). Various factors may cause the serial correlation. Getmansky et al. (2004) find that illiquidity exposure is the most likely

\footnotetext{
${ }^{10}$ Bondarenko (2004) indicate that the value of the variance contract is estimated from prices of traded options, and that the variance return is affected by credit risks and liquidity.
} 
explanation. Share restrictions such as redemption and lockup periods ${ }^{11}$ discourage cash outflows allowing managers to invest in more illiquid assets which affect the HF performance and flowperformance relation. Aragon (2007) and Ding et al. (2009) support the argument of Getmansky et al. (2004). On the other hand, several studies suggest that intentional return smoothing is a possible explanation for the serial correlation. Profiting from lack of transparency and the peculiar fee structure of HFs, managers tend to misreport returns to increase fees. There are several studies investigating the misreporting of HF returns, for instance, those of Bollen and Pool (2009), Agarwal et al. (2009) and Cumming and Dai (2010).

Bollen and Pool (2008) develop an econometric model of a representative managerial algorithm to show whether managers have more desire to smooth losses than gains, which generates conditional serial correlation in reported returns. They report that funds which have been investigated for fraud by the $\mathrm{SEC}^{12}$ are more likely to have a conditional serial correlation. Agarwal et al. (2011a) find higher spikes in December returns compared to those during the rest of the year, and suggest that HFs increase fictitiously their returns during December, by under-reporting returns earlier in the same year, in order to get higher fees. Feng (2010) study the conditional and unconditional return smoothing properties of both live and defunct funds, using gross returns and managerial incentive measures, and conclude that funds with higher managerial incentives tend to be more illiquid and use more intentional return smoothing. Furthermore, they find that higher managerial incentives are also related to conditional return smoothing, which is an indicator of possible fraud. Managers of more illiquid funds tend to earn more incentive fees, whereas funds featuring conditional return smoothing earn lower incentive fees, and failed HFs are more illiquid and more likely to manipulate returns through conditional return smoothing than the rest of funds.

Cumming and Dai (2010) investigate the relationship between misreported returns and HF regulations. They find a positive association between wrappers ${ }^{13}$ and misreporting, particularly for funds that do not have a lockup provision. They also find some evidence that misreporting is less common among funds in jurisdictions with minimum capitalization requirements and restrictions on the location of key service providers ${ }^{14}$. Cassar and Gerakos (2010) investigate the extent to which HF managers smooth selfreported returns by observing the mechanisms used to price the fund's investment positions and report their performance to investors, which enable them to differentiate between asset illiquidity and the misreporting-based explanations. They conclude that funds using less verifiable pricing sources and funds that provide managers with more discretion in pricing investment positions are more likely to

\footnotetext{
${ }^{11}$ Lockup refers to the initial amount of time during which investors are prohibited from withdrawing their investment. The period between two consecutive pre-specified redemption dates is called the redemption period.

${ }^{12}$ SEC: The US securities and exchange commission

${ }^{13}$ Wrappers are financial products which are sold as tied products in order to avoid the same level of regulatory scrutiny as that which would require if sold via other distribution channels.

${ }^{14}$ For HFs key service providers include prime brokers, administrators, and distributors.
} 
have returns consistent with intentional smoothing. Traditional controls, however, such as removing the manager from the setting and reporting of the fund's net asset value and the use of reputable auditors and administrators, are not associated with lower levels of smoothing. With respect to asset illiquidity versus misreporting, investment style and portfolio characteristics explain $14.0-24.3 \%$ of the variation in their smoothing measures, with pricing controls explaining an additional $4.1-8.8 \%$, which suggests that asset illiquidity is the major factor driving the anomalous properties of self-reported HF returns.

\section{$<$ Insert Table 4>}

\section{Risk management characteristics}

\subsection{Risk-return measurements}

Mutual funds (MFs) are considered to be a good starting point to understand the behaviour and performance of HFs since both attract investors due to the return premium they promise. Nevertheless, they use very different investment strategies and mutual funds are much more regulated, for instance they can only hold long positions in liquid assets, and follow frequently a buy-and-hold strategy, whereas HFs follow more dynamic and risky investment strategies.

Early studies such as those of Liang (1999) and Ackermann et al. (1999), compare the risk-return characteristics of HFs and MFs using the Sharpe ratios (for returns) and standard deviations (for risk) and conclude that the HFs offer a better risk-adjusted trade-off than the MFs. Despite this advantage of the HFs over MFs, the above studies also conclude that HFs do not always have higher Sharpe ratios if compared with market indices. This finding has been, however, criticized because the Sharpe ratio used as a risk-adjusted performance measure is based on the mean-variance theory and is, therefore, unable to capture non-normal distribution returns of the HF returns.

Several studies such as those of Fung and Hsieh (1997), Fung and Hsieh (2001), Amin and Kat (2003), Agarwal and Naik (2004), and Eling (2006) show that the use of dynamic option-like trading strategies in HFs leads to nonlinear payoffs. In addition, Lo (2002) argues that the use of the Sharpe ratio in the presence of serial correlation in monthly returns causes an upward bias in the Sharpe ratio, and Goetzmann et al. (2002) shows that it is possible to manipulate the Sharpe ratio using dynamic optionlike strategies which change the probability distribution of the returns. Liang and Park (2007) analyze the risk-return trade-off in HFs using alternative risk measures such as semi-deviation, Value at Risk (VaR), expected shortfall and tail risk, and compare these risk measures with standard deviation, and conclude that skewness and kurtosis should not be ignored in HF risk analysis.

There are limitations on the single risk-return measures such as mean-deviation ratio in terms of capturing the complete risk-return profile for HFs. To avoid such limitations, Kumar et al. (2010) develop a robust framework for HF evaluation using a variety of classical risk-return measures through the implementation of a slack-based data envelopment analysis (DEA) model to determine a single 
performance indicator. They implement the slack-based DEA model using advanced risk-return measurements such as (VaR), Lower and higher partial moments, skewness and drawdown. In addition, they compare the DEA ranking with other traditional financial ratios such as Sharpe ratio, Sortino ratio, and Calmar ratio ${ }^{15}$. This methodology has been adopted by other researchers such as Gregoriou and Rouah (2003), Gregoriou et al. (2005), Nguyen-Thi-Thanh (2006) and Eling (2006).

\section{$<$ Insert Table 5>}

\subsection{Systemic risk}

The scrutiny of HF practices by regulators increased significantly after the attack on sterling by George Soros' fund in 1992 and the Asian financial crisis in 1997. ${ }^{16}$ Eichengreen and Mathieson (1999) conduct a study on the role of HFs in the financial markets, where they investigate the HFs' activities and implications of regulatory policy changes for the financial markets. They interview several major players in the HF industry and conclude that the capital held by HFs poses a small risk compared to the large amount of capital held by other major financial market players such as banks, insurance companies, and corporations, and are of the view that HFs are not able to influence or manipulate market stability and reject the presence of herding behaviour ${ }^{17}$ in the HF industry.

Fung and Hsieh (2000) extend the Eichengreen and Mathieson (1999) work and study the effect of HFs on financial market stability. They obtain mixed results, some supporting the view that HFs did affect the market during the Exchange Rate Mechanism crisis in 1992, the European bond market rally in 1993 and the subsequent decline in 1994, and others showing that HFs did not affect the development of extreme market events such as the stock market crash in 1987, the Mexican Peso Crisis of 1994, the Asian Currency Crisis of 1997, and did not manipulate the markets or had herding behaviours.

After the collapse of Long-Term Capital Management (LTCM) and its subsequent effects on the failure

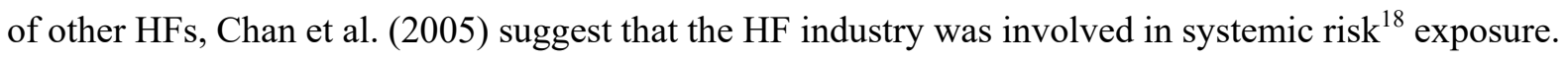
They note that the HF industry has a strong relationship with the banking sector through the banks' trading units that invest in and lend to HFs. Consequently, HFs risk exposures can affect significantly the banking sector increasing systemic risk. Hence, they develop new risk measures for HFs such as illiquidity risk exposure which quantifies the potential effect of HFs on the systemic risk of the market, and use risk models, such as nonlinear factor models and aggregate measures of volatility and financial distress, based on regime-switching.

\footnotetext{
${ }^{15}$ Ratios used to measure the performance of HFs.

${ }^{16}$ Soros's fund earns an estimated $\$ 1.1$ billion from the Bank of England due to its short selling in pounds.

${ }^{17}$ Herding behaviour is the tendency for individuals to mimic the actions (rational or irrational) of a larger group.

${ }^{18}$ Systemic Risk: "The risk of a major and rapid disruption in one or more of the core functions of the financial system caused by the initial failure of one or more financial firms or a segment of the financial system" (see Dixon et al, 2012).
} 
Dixon et al. (2012) examine the extent to which HFs contributed to the increase of systemic risk and subsequent near-collapse of the world's financial system during the 2007 financial crisis and how the recent financial-reform legislation, the Dodd-Frank Wall Street Reform, and Consumer Protection Act of $2010^{19}$, resolves or mitigates the potential systemic risks added by the HFs. They interview 45 respondents, including HF managers, lawyers, investors, regulators, staff of industry associations, congressional staff, researchers and policy analysts, and collect data related to the processes under which HF operate and the HF performance, and conclude that HFs can contribute to systemic risk, but are not the primary cause of the financial crisis and financial stability.

\section{$<$ Insert Table 6>}

\subsection{Risk management practices}

There is a broad debate regarding the use of the Value-at-risk measure (VAR ${ }^{20}$ as an effective risk measure in the HF industry. Several researchers such as Jorion (1999), Alexander and Baptista (2002), Monteiro and Rui (2004), Gupta and Liang (2005), and Bali et al. (2007) study its merits and demerits.

Jorion (1999) investigates the investment strategies of LTCM in terms of its VaR and the amount of capital necessary to support its risk profile ${ }^{21}$ and concludes that the LTCM had severely underestimated risk due to its reliance on short-term history and risk concentration. Furthermore, he highlights some of the risk management lessons learnt from the LTCM failure: (i) the danger of optimization biases which creates huge leverage and extreme sensitivity to instability in the assets value correlations, (ii) the limitations of the traditional risk-management tools which ignore liquidity, and (iii) the problems of using "convergence-arbitrage strategies" since they tend to generate good profits in "normal circumstances" but are prone to big losses when extreme negative fluctuations occur.

Lo (2001) provides an overview of the RM practices used by the HF industry. He argues that traditional $\mathrm{RM}$ tools, such as mean-variance analysis, beta, and VaR do not capture many of the risk exposures underlying HF investments. He describes several RM practices used in the HF industry and provides illustrative examples of the importance of HF in the world's financial system. Alexander and Baptista (2002) analyse the impact of VaR constraints on HF risk-taking imposed for instance by the regulators, and compare the use of VaR constraints with "conditional expected loss" (CEL) constraints ${ }^{22}$ and conclude that The $\mathrm{C}-\mathrm{VaR}$ constraints are tighter than those of VaR making the $\mathrm{C}-\mathrm{VaR}$ a more effective tool to control aggressive risk-taking. Agarwal and Naik (2004) examine the non-linear option-like

\footnotetext{
${ }^{19}$ It is a federal law that brought the most significant changes to financial regulation in the US, affecting every part of the nation's financial service industry including HFs.

${ }^{20} \mathrm{VAR}$ is defined as the maximum loss one expects to suffer at give confidence level by holding a portfolio for a given time.

${ }^{21}$ It has been argued that the failure of LTCM was due to the extremely risky positions, with an abnormal leverage ratio reaching 50:1, posing a significant risk on the fund capital.

${ }^{22}$ Also known as "conditional value at risk" $(\mathrm{C}-\mathrm{VaR})$. The C-VaR is defined as the loss one expects to suffer given that the loss is equal to or larger than the portfolio's VaR.
} 
exposure of HF returns to standard asset classes and observe that a wide range of HF strategies exhibit returns similar to those we obtain from being short in a put option on an equity index, bearing, therefore, a significant left-tail risk. They compare the tail losses of portfolios constructed using the mean-variance framework and the mean conditional VaR framework and show that the former underestimate to some extent the tail losses, especially for portfolios with low volatility. They also argue that the mean conditional value at risk (M-CVaR) measure best suit HFs given that it takes into account the negative tail risk.

Gupta and Liang (2005) use data on around 1,500 HFs to examine the risk characteristics and the capital adequacy of HFs. They use VaR-based capital adequacy measures and conclude that the majority of HFs are adequately capitalized. In addition, they show that VaR-based measures are superior to traditional risk measures (such as standard deviation of returns and leverage ratios) in capturing HF risk, and find that normality based standard deviation measures understate risk and are inappropriate due to the fact that HF's returns exhibit significantly high kurtosis. Moreover, they show that VaR is effective in capturing the underlying risk trends in HF returns that lead to a fund's death. This is evidenced by a significant upward trend in VaR for dead funds while no such trend is observed for live funds. In spite of all the above advantages of the VaR measure, they report some limitations. First, the historical data on which they are based on may not include representative events for the future. Second, the risk profile of an HF may change faster than VaR can capture.

Cassar and Gerakos (2013) examine the determinants and effectiveness of the risk management tools and management practices of HFs. They conclude that the use of risk management practices is a function of HF's characteristics, such as leverage, the number of short/long positions taken, and the capital invested in the HF by the HFM. They further find that funds that use formal RM models, such as VaR, stress testing and scenario analysis, performed relatively better in the extreme down months of 2008 with the magnitudes of these effects being statistically significant. They control for size, age, investment style, portfolio characteristics, and manager education, and show that funds that use at least one model of portfolio risk had returns that were six percentage points higher than funds that did not use any type of model. The funds which employ formal models to evaluate portfolio risk show, however, more accurate return expectations.

\section{$<$ Insert Table 7 $>$}

\section{Conclusion}

This paper summarizes the literature on HF developed over the last two decades, particularly that which relates to risk management practices (a companion piece investigates the managerial characteristics of HFs). It discusses the successes and the shortfalls to date in developing more sophisticated risk management frameworks and tools to measure and monitor HF risks and the empirical evidence on the 
role of the HFs, and their investment behaviour and risk management practices, on the stability of the financial system. It also classifies the HF literature, considering the most recent contributions and, particularly, the regulatory developments after the 2007 financial crisis. A better understanding of the risk-return relationship of HFs is not just important for regulators, investors, and HF managers alike but also represents good business opportunities to the HF industry.

Most of the literature on HF related to risk-return characteristics, report empirical evidence showing a declining in returns and their persistency over time and concludes that some current risk-management techniques are outdated or in need of refinements in order to measure and monitor risk more adequately considering the peculiarities of the HF trading strategies. The literature shows that very often HF managers misreport returns to enhance their funds profile and attract investors and that this behaviour brings the adequacy of the existing regulations into question.

The tables in the Appendix are helpful to identify both the gaps in the HF literature and the most relevant contributions in each research area.

\section{Reference}

1. Ackermann, C., McEnally, R. \& Ravenscraft, D. (1999), "The performance of hedge funds: Risk, return, and incentives." Journal of Finance, Vol. 54, No.3: pp. 833-874.

2. Agarwal, V., Daniel, N. D. \& Naik, N. Y. (2009), "Role of managerial incentives and discretion in hedge fund performance." The Journal of Finance, Vol. 64, No.5: pp. 2221-2256.

3. Agarwal, V., Daniel, N. D. \& Naik, N. Y. (2011a), "Do hedge funds manage their reported returns?" Review of Financial Studies, Vol. 24, No.10: pp. 3281-3320. 
4. Agarwal, V., Fung, W., Loon, Y. C. \& Naik, N. Y. (2011b), "Risk and return in convertible arbitrage: Evidence from the convertible bond market." Journal of Empirical Finance, Vol. 18, No.2: pp. 175-194.

5. Agarwal, V. \& Naik, N. Y. (2004), "Risks and portfolio decisions involving hedge funds." Review of Financial studies, Vol. 17, No.1: pp. 63-98.

6. Alexander, G. J. \& Baptista, A. M. (2002), "Economic implications of using a mean-VaR model for portfolio selection: A comparison with mean-variance analysis." Journal of Economic Dynamics and Control, Vol. 26, No.7-8: pp. 1159-1193.

7. Amin, G. S. \& Kat, H. M. (2003), "Hedge fund performance 1990-2000: Do the "money machines" really add value?" Journal of Financial and Quantitative Analysis, Vol. 38, No.02: pp. 251-274.

8. Aragon, G. (2003), Timing Multiple Markets : Theory and Evidence. Boston College.

9. Aragon, G. (2007), "Share restrictions and asset pricing: Evidence from the hedge fund industry." Journal of Financial Economics, Vol. 83, No.1: pp. 33-58.

10. Bali, T. G., Gokcan, S. \& Liang, B. (2007), "Value at risk and the cross-section of hedge fund returns." Journal of Banking \& Finance, Vol. 31, No.4: pp. 1135-1166.

11. Bares, P.-A., Gibson, R. \& Gyger, S. (2001), "Style consistency and survival probability in the hedge funds industry," EFA 2001 Meetings, at Barcelona, Spain.

12. Berk, J. B. \& Green, R. C. (2004), "Mutual fund flows and performance in rational markets." Journal of Political Economy, Vol. 112, No.6: pp. 1269-1295.

13. Bollen, N. P. \& Pool, V. K. (2008), "Conditional return smoothing in the hedge fund industry." Journal of Financial and Quantitative Analysis, Vol. 43, No.02: pp. 267-298.

14. Bollen, N. P. B. \& Pool, V. K. (2009), "Do Hedge Fund Managers Misreport Returns? Evidence from the Pooled Distribution." The Journal of Finance, Vol. 64, No.5: pp. 2257-2288.

15. Bondarenko, O. (2004), "Market price of variance risk and performance of hedge funds," AFA 2006 Paper, at Boston, USA.

16. Brown, S. J. \& Goetzmann, W. N. (2001), "Hedge funds with style." Journal of Portfolio Management, Vol. 29, No.2: pp. 101-112.

17. Cai, L. \& Liang, B. (2012), "On the Dynamics of Hedge Fund Strategies." The Journal of Alternative Investments, Vol. 14, No.4: pp. 51-68.

18. Carhart, M. M. (1997), "On persistence in mutual fund performance." The Journal of Finance, Vol. 52, No.1: pp. 57-82.

19. Cassar, G. \& Gerakos, J. (2010), "Determinants of hedge fund internal controls and fees." The Accounting Review, Vol. 85, No.6: pp. 1887-1919.

20. Cassar, G. \& Gerakos, J. (2013), Does risk management work? Chicago Booth.

21. Chan, N., Getmansky, M., Haas, S. M. \& Lo, A. W. (2005), Systemic risk and hedge funds. National Bureau of Economic Research.

22. Cumming, D. \& Dai, N. (2010), "Hedge fund regulation and misreported returns." European Financial Management, Vol. 16, No.5: pp. 829-857.

23. Ding, B., Getmansky, M., Liang, B. \& Wermers, R. (2009), Share restrictions and investor flows in the hedge fund industry. Univeristy of Massachusetts at Amherst

24. Dixon, L., Clancy, N. \& Kumar, K. B. (2012), "Hedge funds and systemic risk," Rand Corporation.

25. Dor, A. B., Jagannathan, R. \& Meier, I. (2003), "Understanding mutual fund and hedge fund styles using return-based style analysis." Journal of Investment Management, Vol. 1, No.1: pp. 94-134.

26. Eichengreen, B. J. \& Mathieson, D. J. (1999), "Hedge Funds: What do we really know?," International Monetary Fund.

27. Eling, M. (2006), "Performance measurement of hedge funds using data envelopment analysis." Financial Markets and Portfolio Management, Vol. 20, No.4: pp. 442-471.

28. Feng, S. (2010), Return Smoothing, Managerial Incentives, and Hedge Funds Failures. Eastern Finance Association. Savannah, GA.

29. Fung, W., Hsieh, D., Naik, N. \& Ramadorai, T. (2005), Lessons from a decade of hedge fund performance: Is the party over or the beginning of a new paradigm?, London Business School. 
30. Fung, W. \& Hsieh, D. A. (1997), "Empirical characteristics of dynamic trading strategies: The case of hedge funds." Review of Financial Studies, Vol. 10, No.2: pp. 275-302.

31. Fung, W. \& Hsieh, D. A. (2000), "Measuring the market impact of hedge funds." Journal of Empirical Finance, Vol. 7, No.1: pp. 1-36.

32. Fung, W. \& Hsieh, D. A. (2001), "The risk in hedge fund strategies: Theory and evidence from trend followers." Review of Financial Studies, Vol. 14, No.2: pp. 313-341.

33. Fung, W. \& Hsieh, D. A. (2002), "Risk in fixed-income hedge fund styles." The Journal of Fixed Income, Vol. 12, No.2: pp. 6-27.

34. Fung, W. \& Hsieh, D. A. (2004a), "Extracting portable alphas from equity long-short hedge funds." Journal of Investment Management, Vol. 2, No.4: pp. 1-19.

35. Fung, W. \& Hsieh, D. A. (2004b), "Hedge fund benchmarks: A risk-based approach." Financial Analysts Journal, Vol. 60, No.5: pp. 65-80.

36. Fung, W. \& Hsieh, D. A. (2007), "Hedge fund replication strategies: implications for investors and regulators." Financial Stability Review, Vol. 10, No.1: pp. 55-66.

37. Fung, W., Hsieh, D. A., Naik, N. Y. \& Ramadorai, T. (2008), "Hedge funds: Performance, risk, and capital formation." The Journal of Finance, Vol. 63, No.4: pp. 1777-1803.

38. Fung, W., Xu, X. E. \& Yau, J. (2002), "Hedge and Funds : Market Timing Return, and Market Timing." Financial Analysts Journal Vol. 58, No.6 pp. 19-30.

39. Getmansky, M., Lo, A. W. \& Makarov, I. (2004), "An econometric model of serial correlation and illiquidity in hedge fund returns." Journal of Financial Economics, Vol. 74, No.3: pp. 529609.

40. Goetzmann, W., Ingersoll, J., Spiegel, M. I. \& Welch, I. (2002), Sharpening sharpe ratios. National Bureau of Economic Research.

41. Gregoriou, G. N. \& Rouah, F. (2003), "Large versus Small Hedge Funds: Does Size Affect Performance? ." Journal of Alternative Investments Vol. 5, No.3 pp. 75-84.

42. Gregoriou, G. N., Sedzro, K. \& Zhu, J. (2005), "Hedge fund performance appraisal using data envelopment analysis." European Journal of Operational Research, Vol. 164, No.2: pp. 555571.

43. Gupta, A. \& Liang, B. (2005), "Do hedge funds have enough capital? A value-at-risk approach." Journal of Financial Economics, Vol. 77, No.1: pp. 219-253.

44. Jorion, P. (1999), "Risk management lessons from long-term capital management." European Financial Management, Vol. 6, No.3: pp. 277-300.

45. Kosowski, R., Naik, N. Y. \& Teo, M. (2007), "Do hedge funds deliver alpha? A Bayesian and bootstrap analysis." Journal of Financial Economics, Vol. 84, No.1: pp. 229-264.

46. Kumar, U. D., Roy, A., Saranga, H. \& Singal, K. (2010), "Analysis of hedge fund strategies using slack-based DEA models." Journal of the Operational Research Society, Vol. 61, No.12: pp. $1746-1760$.

47. Liang, B. (1999), "On the performance of hedge funds." Financial Analysts Journal Vol. 55, No.4 pp. $72-85$.

48. Liang, B. \& Park, H. (2007), "Risk measures for hedge funds: a cross-sectional approach." European Financial Management, Vol. 13, No.2: pp. 333-370.

49. Lo, A. (2001), "Risk management for hedge funds: Introduction and overview." Financial Analysts Journal, Vol. 57, No.6: pp. 113-123.

50. Lo, A. W. (2002), "The statistics of Sharpe ratios." Financial Analysts Journal, Vol. 58, No.4: pp. 36-52.

51. Maillet, B. \& Rousset, P. (2003), "Classifying hedge funds with Kohonen maps: a first attempt." Connectionist Approaches in Economics and Management Sciences. Springer: pp. 233-259.

52. Merton, R. (1981), "On Market Timing and Investment Performance." The Journal of Business, Vol. 54, No.3 pp. 363-406.

53. Mitchell, M. \& Pulvino, T. (2001), "Characteristics of risk and return in risk arbitrage." The Journal of Finance, Vol. LVI, No.1: pp. 2135-2175.

54. Monteiro, P. V. \& Rui, P. (2004), Forecasting hedge funds volatility: A risk management approach. Available at SSRN 570065.

55. Naik, N. Y., Ramadorai, T. \& Stromqvist, M. (2007), "Capacity constraints and hedge fund strategy returns." European Financial Management, Vol. 13, No.2: pp. 239-256. 
56. Nguyen-Thi-Thanh, H. (2006), On the use of data envelopment analysis in hedge fund selection. Univeriste d'orleans.

57. Pastor, L. \& Stambaugh, R. F. (2009), "Predictive systems: Living with imperfect predictors." The Journal of Finance, Vol. 64, No.4: pp. 1583-1628.

58. Patton, A. J. (2009), "Are "market neutral" hedge funds really market neutral?" Review of Financial Studies, Vol. 22, No.7: pp. 2495-2530.

59. Sharpe, W. F. (1992), "Asset allocation: Management style and performance measurement." The Journal of Portfolio Management, Vol. 18, No.2: pp. 7-19. 


\section{Appendix}

Table 1 - Describes the components of HF returns and the literature examining their market neutrality

\begin{tabular}{|c|c|c|c|c|c|c|}
\hline Name & Objective & Modelling/Framework & Findings & Database & Sample & Period \\
\hline \multirow{2}{*}{ Liang (1998) } & $\begin{array}{l}\text { Study market neutrality of HFs } \\
\text { with traditional asset classes }\end{array}$ & Eight asset class factor model & $\begin{array}{l}\text { Low correlation between HFs and traditional asset } \\
\text { classes }\end{array}$ & \multirow{2}{*}{ HFR } & \multirow{2}{*}{385} & \multirow{2}{*}{$\begin{array}{l}\text { Jan. 1994- Dec. } \\
1996\end{array}$} \\
\hline & $\begin{array}{l}\text { Study correlation among } \\
\text { different HF strategies }\end{array}$ & Correlation Analysis & $\begin{array}{l}\text { Low correlation among different HF strategies, } \\
\text { which make HFs better diversification pools }\end{array}$ & & & \\
\hline Patton (2009) & Test market neutrality & $\begin{array}{l}\text { Divide market neutrality into five different } \\
\text { concepts and apply correlation analysis on } \\
\text { each concept individually }\end{array}$ & $\begin{array}{l}\text { Only one-quarter of the funds exhibits significant } \\
\text { exposure to market risks }\end{array}$ & $\begin{array}{l}\text { HFR and } \\
\text { TASS }\end{array}$ & 1423 & $\begin{array}{l}\text { April } 1993 \text { to April } \\
2003\end{array}$ \\
\hline $\begin{array}{l}\text { Cai and Liang } \\
\text { (2012) }\end{array}$ & $\begin{array}{l}\text { Study market neutrality while } \\
\text { reducing the auto-correlation } \\
\text { residuals in each fund style }\end{array}$ & Dynamic linear regression model & $\begin{array}{l}\text { Equity market neutral has a close to neutral } \\
\text { exposure and a better neutrality than other HF } \\
\text { styles }\end{array}$ & TASS & $\begin{array}{l}3102(1590 \\
\text { live, } 1512 \\
\text { defunct })\end{array}$ & $\begin{array}{l}\text { Jan. 1994- Dec. } \\
2008\end{array}$ \\
\hline \multirow{2}{*}{$\begin{array}{l}\text { Fung and Hsieh } \\
\text { (1997) }\end{array}$} & \multirow{2}{*}{$\begin{array}{l}\text { Modelling risk and return for } \\
\text { different HF strategies }\end{array}$} & $\begin{array}{l}\text { 1- Factor analysis to determine the dominant } \\
\text { style in HFs ( Principle component analysis) }\end{array}$ & $\begin{array}{l}\text { They classify five mutually orthogonal principal } \\
\text { components }\end{array}$ & \multirow{2}{*}{$\begin{array}{l}\text { Paradigm } \\
\text { LDC and } \\
\text { TASS }\end{array}$} & \multirow{2}{*}{$\begin{array}{l}409 \text { ( HFs } \\
\text { and CTA ) }\end{array}$} & \multirow{2}{*}{ 1993- 1995} \\
\hline & & $\begin{array}{l}\text { 2- Extension of Sharpe (1992) model to } \\
\text { extract style factors on nine asset class model }\end{array}$ & $\begin{array}{l}\text { Value and Distressed styles are location choice, } \\
\text { whereas system traders, system/opportunistic, and } \\
\text { global macro are dynamic trading strategies }\end{array}$ & & & \\
\hline \multirow{2}{*}{$\begin{array}{l}\text { Brown and } \\
\text { Goetzmann } \\
(2003)\end{array}$} & \multirow{2}{*}{$\begin{array}{l}\text { Analyzing risk-return } \\
\text { characteristics of different } \mathrm{HF} \\
\text { styles }\end{array}$} & \multirow[b]{2}{*}{ Extension of k-mean cluster analysis } & Classified eight different styles employed by HFs & \multirow[b]{2}{*}{ TASS } & \multirow[b]{2}{*}{1296} & \multirow[b]{2}{*}{ 1989-1999 } \\
\hline & & & $\begin{array}{l}20 \% \text { of the cross-sectional variability of fund } \\
\text { returns can be explained by each style }\end{array}$ & & & \\
\hline $\begin{array}{l}\text { Bares et al. } \\
(2001)\end{array}$ & $\begin{array}{l}\text { Examine style consistency in } \\
\text { HFs }\end{array}$ & Hard and Fuzzy clustering analysis & $\begin{array}{l}\text { Investment style of a manager may depart from his } \\
\text { reported style over time }\end{array}$ & FRM & 235 & $\begin{array}{l}\text { May 1994-April } \\
\text { 1998, May 1998- } \\
\text { April 1999 ( out of } \\
\text { sample) }\end{array}$ \\
\hline $\begin{array}{l}\text { Maillet and } \\
\text { Rousset (2001) }\end{array}$ & $\begin{array}{l}\text { Characterize families of HFs } \\
\text { and defining a representative } \\
\text { fund for each class }\end{array}$ & Kohonen classification mapping & $\begin{array}{l}\text { Identify a set of representative HFs which may } \\
\text { also be used as benchmarks for style analysis of } \\
\text { funds }\end{array}$ & Micropal & 471 & $\begin{array}{l}\text { Jan. 1995- Sept. } \\
2000\end{array}$ \\
\hline
\end{tabular}


Table 2 - Documents the literature investigating the nonlinearity of HF returns and their main characteristics

\begin{tabular}{|c|c|c|c|c|c|c|}
\hline Name & Objective & Modelling/Framework & Findings & Database & Sample & Period \\
\hline \multirow{2}{*}{$\begin{array}{l}\text { Fung and Hsieh } \\
(2001)\end{array}$} & \multirow{2}{*}{$\begin{array}{l}\text { Test market neutrality in the 'trend } \\
\text { following' strategy within a non-linear } \\
\text { context }\end{array}$} & \multirow{2}{*}{$\begin{array}{l}\text { Asset-based style model/ Option- } \\
\text { based strategy by using look- } \\
\text { back straddles to model trend- } \\
\text { following strategies }\end{array}$} & $\begin{array}{l}\text { Proves the existence of a non-linear } \\
\text { relationship between the trend followers' } \\
\text { returns and equity market. }\end{array}$ & \multirow[t]{2}{*}{ TASS } & \multirow[t]{2}{*}{407} & \multirow{2}{*}{$\begin{array}{l}\text { Mar. 1985- Dec. } \\
1997\end{array}$} \\
\hline & & & $\begin{array}{l}\text { Confirm that trend-following funds have } \\
\text { systematic risk and are not market neutral }\end{array}$ & & & \\
\hline $\begin{array}{l}\text { Fung and Hsieh } \\
(2007)\end{array}$ & $\begin{array}{l}\text { Provide an out of sample verification for } \\
\text { Fung and Hsieh (2001) results }\end{array}$ & Out of sample test & $\begin{array}{l}\text { Fung and Hsieh (2001) correctly predict the } \\
\text { return behaviour of trend-following } \\
\text { strategies during the out of sample period }\end{array}$ & TASS & NA & $\begin{array}{l}\text { Jan.1998- June } \\
2006\end{array}$ \\
\hline $\begin{array}{l}\text { Mitchell and } \\
\text { Pulvino (2001) }\end{array}$ & $\begin{array}{l}\text { Characterize the risk-return relationship } \\
\text { in risk arbitrage HFs }\end{array}$ & Asset-based style model & $\begin{array}{l}\text { Risk arbitrage returns are positively } \\
\text { correlated with market returns during } \\
\text { downturn conditions. In contrast, they have } \\
\text { zero correlation during normal market } \\
\text { conditions }\end{array}$ & No Database & $\begin{array}{l}4750 \text { merger } \\
\text { transactions } \\
\text { used by risk } \\
\text { arbitrage HFs }\end{array}$ & 1963-1998 \\
\hline $\begin{array}{l}\text { Fung and Hsieh } \\
\text { (2002) }\end{array}$ & $\begin{array}{l}\text { Analyze the common risk factors of } \\
\text { fixed-income HFs }\end{array}$ & Asset-based style model & $\begin{array}{l}\text { The majority of fixed-income HFs are } \\
\text { exposed to a large increase in credit spreads }\end{array}$ & HFR & NA & $1998-2000$ \\
\hline $\begin{array}{l}\text { Agarwal et al. } \\
(2004)\end{array}$ & $\begin{array}{l}\text { Analyze the risk-return characteristics of } \\
\text { convertible arbitrage funds }\end{array}$ & Asset-based style model & $\begin{array}{l}\text { Theorizes the existence of three 'Primitive } \\
\text { Trading Strategies' that can justify the } \\
\text { convertible arbitrage fund's returns namely, } \\
\text { volatility arbitrage, positive carry, and credit } \\
\text { arbitrage }\end{array}$ & NA & $\begin{array}{l}539 \text { Japanese } \\
\text { and } 1234 \text { US } \\
\text { convertible } \\
\text { bonds }\end{array}$ & $\begin{array}{l}\text { April 1993-Jan. } \\
2002\end{array}$ \\
\hline \multirow[t]{2}{*}{$\begin{array}{l}\text { Agarwal et al. } \\
(2011 \mathrm{~b})\end{array}$} & $\begin{array}{l}\text { Study the empirical characteristics of the } \\
\text { key drivers of convertible arbitrage } \\
\text { strategies and how they impact } \\
\text { performance }\end{array}$ & $\begin{array}{l}\text { Asset-based style model to create } \\
\text { a hedged convertible bonds } \\
\text { portfolio over time }\end{array}$ & $\begin{array}{l}\text { 1- They compute the returns to a buy-and- } \\
\text { hedge strategy and show that such a strategy } \\
\text { together with a simple buy-and-hold strategy } \\
\text { can explain a large proportion of the return } \\
\text { variation. in convertible arbitrage hedge } \\
\text { funds. }\end{array}$ & \multirow[t]{2}{*}{ Albourne Partners } & \multirow[t]{2}{*}{$\begin{array}{l}1646 \text { US } \\
\text { convertible } \\
\text { bonds }\end{array}$} & \multirow[t]{2}{*}{$\begin{array}{l}\text { Jan. 1993-April } \\
2003\end{array}$} \\
\hline & & & $\begin{array}{l}\text { 2- The importance of non-price variables } \\
\text { such as extreme market-wide events and the } \\
\text { supply of convertible bonds on performance. }\end{array}$ & & & \\
\hline
\end{tabular}




\begin{tabular}{|c|c|c|c|c|c|c|}
\hline \multirow{2}{*}{$\begin{array}{l}\text { Agarwak and } \\
\text { Naik (2004) }\end{array}$} & \multirow{2}{*}{$\begin{array}{l}\text { Characterize the non-linear systematic } \\
\text { risk exposures of a wide range of HF } \\
\text { strategies }\end{array}$} & \multirow{2}{*}{$\begin{array}{l}\text { Option-based risk multi-factors } \\
\text { model }\end{array}$} & \multirow{2}{*}{$\begin{array}{l}\text { The ability to identify and test the systematic } \\
\text { risk factors affecting hedge fund } \\
\text { performance }\end{array}$} & HFR & \multirow[b]{2}{*}{ NA } & $\begin{array}{l}\text { Jan. 1990- June } \\
2000\end{array}$ \\
\hline & & & & $\begin{array}{l}\text { CSFB/Tremont } \\
\text { index }\end{array}$ & & $\begin{array}{l}\text { Jan. 1994- June } \\
2000\end{array}$ \\
\hline \multirow{2}{*}{$\begin{array}{l}\text { Fung and Hsieh } \\
\text { (2004b) }\end{array}$} & \multirow{2}{*}{$\begin{array}{l}\text { Propose a risk factor model that can be } \\
\text { applied to different HF strategies and } \\
\text { can overcome the drawbacks of } \\
\text { conventional asset-based models }\end{array}$} & \multirow[t]{2}{*}{$\begin{array}{l}\text { Arbitrage price theory (APT) } \\
\text { model }\end{array}$} & $\begin{array}{l}\text { 1- Providing a standardized framework for } \\
\text { measuring hedge funds performance while } \\
\text { taking into account both time-varying and } \\
\text { nonlinear risk characteristics }\end{array}$ & TASS & 1821 & \multirow{2}{*}{$\begin{array}{l}\text { Jan. 1994- Dec. } \\
2002\end{array}$} \\
\hline & & & $\begin{array}{l}\text { 2- Providing a link between conventional } \\
\text { asset class risks and hedge fund risks }\end{array}$ & HFR & 1911 & \\
\hline
\end{tabular}


Table 3- The main articles examining the persistency of HFs' alpha and their implications

\begin{tabular}{|c|c|c|c|c|c|c|}
\hline Name & Objective & Modelling/Framework & Findings & Database & Sample & Period \\
\hline $\begin{array}{l}\text { Fung and } \\
\text { Hsieh (2004a) }\end{array}$ & $\begin{array}{l}\text { Empirically study the existence of } \\
\text { alpha with both conventional and } \\
\text { alternative risk factors in equity } \\
\text { long/short funds }\end{array}$ & $\begin{array}{l}\text { Fama-French three-factor model augmented } \\
\text { with the momentum factor as implemented } \\
\text { by (Carhart, 1997) }\end{array}$ & $\begin{array}{l}\text { The size factor turns out to be the most important } \\
\text { risk factor, whereas the book-to-market and } \\
\text { momentum factors are statistically insignificant }\end{array}$ & $\begin{array}{l}\text { TASS, HFR, } \\
\text { MSCI }\end{array}$ & NA & $1996-2002$ \\
\hline \multirow{3}{*}{$\begin{array}{l}\text { Kowsowski et } \\
\text { al. (2007) }\end{array}$} & $\begin{array}{l}\text { 1- Test whether fund managers are } \\
\text { responsible for generating superior } \\
\text { performance (alpha) over time or it is } \\
\text { just luck }\end{array}$ & Bootstrap methodology & $\begin{array}{l}\text { 1- The existence of annual persistence in the HF's } \\
\text { alphas indicating that these alphas cannot be } \\
\text { attributed to luck alone }\end{array}$ & \multirow{3}{*}{$\begin{array}{l}\text { CISDM, TASS, } \\
\text { HFR, and } \\
\text { MSCI }\end{array}$} & \multirow{3}{*}{$\begin{array}{l}4300 \text { live } \\
\text { funds and } \\
1233 \text { dead } \\
\text { funds }\end{array}$} & \multirow{2}{*}{$\begin{array}{l}\text { Jan. } 1990- \\
\text { Dec. } 2002\end{array}$} \\
\hline & $\begin{array}{l}\text { 2- Comparing the alphas using two } \\
\text { models }\end{array}$ & Bayesian Approach vs. OLS Approach & $\begin{array}{l}\text { 2- Applying Bayesian approach to OLS increases } \\
\text { the alpha yield with } 5.5 \% \text { difference between the } \\
\text { top and bottom hedge funds deciles }\end{array}$ & & & \\
\hline & $\begin{array}{l}\text { 3- Testing Alpha's persistence over } \\
\text { time }\end{array}$ & Bayesian model & $\begin{array}{l}\text { 3-Confirm the persistence of alpha over time with a } \\
\text { declining trend due to the fund's capital growth } \\
\text { (Berk and Green 2004) model. }\end{array}$ & & & $\begin{array}{l}\text { Jan. } 1996- \\
\text { Dec. } 2002\end{array}$ \\
\hline \multirow{3}{*}{$\begin{array}{l}\text { Fung et al. } \\
(2005)\end{array}$} & $\begin{array}{l}\text { 1- The effect of alphas on determining } \\
\text { the quality of Funds of Hedge Funds }\end{array}$ & Regression analysis & $\begin{array}{l}\text { 1- Funds enjoying significant and positive alphas do } \\
\text { have less survivorship risk and take smaller beta } \\
\text { bets than those who do not have }\end{array}$ & \multirow{3}{*}{$\begin{array}{l}\text { TASS, HF, and } \\
\text { CISDM }\end{array}$} & \multirow{3}{*}{$\begin{array}{l}996 \text { (Fund } \\
\text { of Hedge } \\
\text { Funds) only }\end{array}$} & \multirow{3}{*}{$\begin{array}{l}\text { Jan. 1988- } \\
\text { Dec } 2002\end{array}$} \\
\hline & $\begin{array}{l}\text { 2- Study the effect of structural breaks } \\
\text { on alpha }\end{array}$ & $\begin{array}{l}\text { Divide the sample into three sub-samples } \\
\text { (Pre-LTCM, Internet bubble, and recent } \\
\text { period ) }\end{array}$ & $\begin{array}{l}\text { 2- The (HAVE) alpha funds exhibit a statistically } \\
\text { significant alpha over the three periods in a } \\
\text { declining trend. whereas the (HAVE-not) group } \\
\text { only delivered significant alpha during the second } \\
\text { period }\end{array}$ & & & \\
\hline & $\begin{array}{l}\text { 3- Identify the main sources of alpha } \\
\text { over time }\end{array}$ & $\begin{array}{l}\text { Style analysis for each fund individually in } \\
\text { line with Sharpe (1992) }\end{array}$ & $\begin{array}{l}\text { 3- The supply of alpha is cyclical depending on } \\
\text { both market environment and hedge fund style }\end{array}$ & & & \\
\hline $\begin{array}{l}\text { Fung et al. } \\
\text { (2008) }\end{array}$ & $\begin{array}{l}\text { Testing Alpha's persistence over time } \\
\text { on FoHFs }\end{array}$ & 7-factors linear regression model & $\begin{array}{l}\text { Confirms the persistence of alpha over time with a } \\
\text { declining trend due to the funds' capital growth } \\
\text { (Berk and Green 2004) model. }\end{array}$ & $\begin{array}{l}\text { HFR, CISDM, } \\
\text { TASS }\end{array}$ & $\begin{array}{l}1158 \text { funds } \\
\text { in } 2004\end{array}$ & $\begin{array}{l}\text { Jan. } 1995- \\
\text { Dec. } 2004\end{array}$ \\
\hline
\end{tabular}




\begin{tabular}{|c|c|c|c|c|c|c|}
\hline $\begin{array}{l}\text { Naik et al. } \\
(2007)\end{array}$ & $\begin{array}{l}\text { Examine whether the capacity } \\
\text { constraints at the level of HF strategy } \\
\text { is behind the declining trend of alpha } \\
\text { over time }\end{array}$ & $\begin{array}{l}\text { 7-factors linear regression model and } 4 \text { non- } \\
\text { options factor model }\end{array}$ & $\begin{array}{l}\text { Existence of capital constraints at the level of hedge } \\
\text { fund strategies }\end{array}$ & $\begin{array}{l}\text { HFR, CISDM, } \\
\text { TASS, and } \\
\text { MSCI }\end{array}$ & 7610 & $\begin{array}{l}\text { Jan. 1994- } \\
\text { Dec. } 2004\end{array}$ \\
\hline \multirow{3}{*}{$\begin{array}{l}\text { Fung and } \\
\text { Hsieh (2011) }\end{array}$} & $\begin{array}{l}\text { 1- Investigate alpha persistency in } \\
\text { equity L/S HFs }\end{array}$ & Standard 4-factors model & $\begin{array}{l}\text { 1- Less than } 20 \% \text { of the sample exhibit's significant } \\
\text { alpha over time which confirms Berk and Green } \\
\text { (2004) model }\end{array}$ & \multirow{3}{*}{$\begin{array}{l}\text { TASS, HFR, } \\
\text { and CISDM }\end{array}$} & \multirow{3}{*}{$\begin{array}{l}3038 \text { Equity } \\
\text { HFs }\end{array}$} & \multirow{3}{*}{ 1994-2008 } \\
\hline & \multirow{2}{*}{$\begin{array}{l}\text { 2- Study the main drivers of alpha } \\
\text { beyond the conventional approach }\end{array}$} & \multirow{2}{*}{$\begin{array}{l}\text { Introducing non-price variables to the } 4 \text { - } \\
\text { factors model }\end{array}$} & $\begin{array}{l}\text { 1- L/S equity HFs depends on the access to the } \\
\text { stock loan market and the level of stock market } \\
\text { activity to deliver higher alpha }\end{array}$ & & & \\
\hline & & & $\begin{array}{l}\text { 2- Lower levels of aggregate short sales interest } \\
\text { enhance the manager's ability to take more short } \\
\text { positions delivering higher alpha }\end{array}$ & & & \\
\hline $\begin{array}{l}\text { Bondarenko } \\
(2004)\end{array}$ & $\begin{array}{l}\text { Study the superior risk-adjusted } \\
\text { returns after accounting for the value } \\
\text { of variance contracts }\end{array}$ & $\begin{array}{l}\text { Including the variance risk in the risk-factor } \\
\text { model }\end{array}$ & $\begin{array}{l}\text { The performance of HFs delivers negative alphas } \\
\text { after accounting for the variance risk exposure }\end{array}$ & $\begin{array}{l}\text { HFR index and } \\
\text { CSFB/Tremont } \\
\text { index }\end{array}$ & $\begin{array}{l}1400 \mathrm{HFs} \\
\text { for HFR } \\
\text { and } 3000 \\
\text { HFs for } \\
\text { CSFB }\end{array}$ & 1988- 2000 \\
\hline Aragon (2003) & $\begin{array}{l}\text { The effect of Liquidity on the funds of } \\
\text { hedge funds' alpha }\end{array}$ & $\begin{array}{l}\text { An extension of the market-timing model of } \\
\text { Merton (1981) }\end{array}$ & $\begin{array}{l}\text { Finds a positive, concave relationship between HF } \\
\text { returns and restrictions imposed by private } \\
\text { investment funds. Reports a } 4-7 \% \text { higher alpha for } \\
\text { lockup restricted funds compared to non-lockup } \\
\text { funds }\end{array}$ & TASS & $\begin{array}{l}299 \text { Fund of } \\
\text { Hedge } \\
\text { funds }\end{array}$ & 1994- 2002 \\
\hline
\end{tabular}




\section{Table 4- Provide a summary of literature examining the intentional return smoothing of HFs}

\begin{tabular}{|c|c|c|c|c|c|c|}
\hline Name & Objective & Modelling/Framework & Findings & Database & Sample & Period \\
\hline \multirow[b]{2}{*}{$\begin{array}{l}\text { Getmansky et } \\
\text { al. (2004) }\end{array}$} & $\begin{array}{l}\text { The existence of serial correlation } \\
\text { in HF returns }\end{array}$ & & High serial correlation of $12.1 \%$ in the HF returns & \multirow[b]{2}{*}{ TASS } & \multirow[b]{2}{*}{909} & \multirow[b]{2}{*}{$\begin{array}{l}\text { Nov. 1977- } \\
\text { Jan. } 2001\end{array}$} \\
\hline & $\begin{array}{l}\text { Reasons behind the serial } \\
\text { correlation }\end{array}$ & $\begin{array}{l}\text { Unconditional return smoothing } \\
\text { model/ Observed betas, SD, and } \\
\text { Sharp ratios/ Regression Analysis }\end{array}$ & $\begin{array}{l}\text { Illiquidity exposure is the main reason for serial correlation. } \\
\text { Share restrictions such as redemption and lockup periods } \\
\text { discourage cash outflows allowing managers to invest in more } \\
\text { illiquid assets which in turn affects the hedge fund } \\
\text { performance and flow-performance relation }\end{array}$ & & & \\
\hline Aragon (2007) & Measuring fund asset illiquidity & Probit Analysis & $\begin{array}{l}\text { A positive relationship between a fund's underlying asset } \\
\text { illiquidity and the use of share restrictions }\end{array}$ & TASS & 2873 & $\begin{array}{l}\text { Jan. 1994- } \\
\text { Dec. } 2001\end{array}$ \\
\hline $\begin{array}{l}\text { Ding et al. } \\
\text { (2010) }\end{array}$ & $\begin{array}{l}\text { Analyze the impact of share } \\
\text { restrictions of individual HFs on } \\
\text { the fund flow-performance } \\
\text { relation }\end{array}$ & $\begin{array}{l}\text { Piecewise linear relationship/ } \\
\text { Regression Analysis }\end{array}$ & $\begin{array}{l}\text { A concave relationship between find restrictions such as } \\
\text { lockup and redemption notice and fund flow-Performance }\end{array}$ & TASS & 4594 & 1994- 2004 \\
\hline \multirow{2}{*}{$\begin{array}{l}\text { Bollen \& Pool } \\
(2008)\end{array}$} & \multirow{2}{*}{$\begin{array}{l}\text { Examine whether managers have } \\
\text { more desire to smooth losses than } \\
\text { gains, which generates } \\
\text { conditional serial correlation in } \\
\text { reported returns }\end{array}$} & \multirow{2}{*}{ Conditional serial correlation } & $\begin{array}{l}\text { Funds possessing conditional serial correlation tend to have an } \\
\text { increased risk of capital flight, as measured by volatility and } \\
\text { investor cash flows }\end{array}$ & \multirow{2}{*}{ CISDM } & \multirow{2}{*}{ NA } & 1994- 2003 \\
\hline & & & $\begin{array}{l}\text { Funds which have been investigated for fraud by the SEC are } \\
\text { much more likely to possess conditional serial correlation than } \\
\text { other funds. }\end{array}$ & & & $\begin{array}{l}\text { Dec. 2004- } \\
\text { Oct. } 2009\end{array}$ \\
\hline \multirow{2}{*}{$\begin{array}{l}\text { Agarwal et al. } \\
\text { (2011a) }\end{array}$} & \multirow{2}{*}{$\begin{array}{l}\text { Do HFs manage their reported } \\
\text { return in an opportunistic } \\
\text { fashion? }\end{array}$} & \multirow{2}{*}{$\begin{array}{l}\text { Gross returns and managerial } \\
\text { incentive measures }\end{array}$} & $\begin{array}{l}\text { Higher spikes in December returns for HFs with greater } \\
\text { incentives and greater opportunities to inflate returns whether } \\
\text { to report higher gains or reduce losses in order to earn higher } \\
\text { fees. }\end{array}$ & \multirow{2}{*}{$\begin{array}{l}\text { CISDM, } \\
\text { HFR, MSCI, } \\
\text { TASS, and } \\
\text { Eureka }\end{array}$} & \multirow{2}{*}{11305} & \multirow{2}{*}{$\begin{array}{l}\text { Jan. } 1994- \\
\text { Dec. } 2006\end{array}$} \\
\hline & & & $\begin{array}{l}\text { Evidence of funds inflating their December returns by under- } \\
\text { reporting returns earlier in the year but only weak evidence } \\
\text { that funds borrow from January returns in the following year. }\end{array}$ & & & \\
\hline
\end{tabular}


Funds with higher managerial incentives tend to have more

illiquidity and return smoothing.

Higher managerial incentives are also related to conditiona

return smoothing, which is a leading indicator of fraud.

Conditional and unconditiona return smoothing properties both live and defunct funds
Gross returns and manageria incentive measures
Investigate the relationship

Cumming \&

Dai (2010)

between $\mathrm{mistc}$

hedge fund regulations
Regression Analysis

(1)

Managers of more illiquid funds tend to earn more incentive TASS

fees, but funds featuring funds tend to earn more incentive

lower incentive fees on average.

Evidence that failed HFs are more illiquid and more likely to manipulate returns through conditional return smoothing than the rest of funds.

A positive association between wrappers and misreporting, particularly for funds that do not have a lockup provision.

Some evidence that misreporting is less common among fund

in jurisdictions with minimum capitalization requirements and

restrictions on the location of key service providers.

\section{$8641 \quad$ Jan. 1994 \\ Dec. 2008}

Funds using less verifiable pricing sources and funds that provide managers with greater discretion in pricing investmen positions are more likely to have returns consistent with

intentional smoothing

Investment style and portfolio characteristics explain 14.0-

$24.3 \%$ of the variation in their smoothing measures, and

pricing controls explain an additional $4.1-8.8 \%$, suggesting

that asset illiquidity is the major factor driving the anomalou

properties of self-reported HF returns 
Table 5- The main Risk-Return measurements used in the HF industry

\begin{tabular}{|c|c|c|c|c|c|c|}
\hline Name & Objective & Modelling/Framework & Findings & Database & Sample & Period \\
\hline Liang (1999) & $\begin{array}{l}\text { 1- Analyze HF performance with regard to its } \\
\text { risk. 2- Comparing HFs' performance vs. } \\
\text { MFs. }\end{array}$ & $\begin{array}{l}\text { Sharpe ratio, standard } \\
\text { deviation }\end{array}$ & HFs offer better risk-adjusted return than MFs & HFR & 385 & $\begin{array}{l}\text { Jan. } 1994- \\
\text { Dec. } 1996\end{array}$ \\
\hline $\begin{array}{l}\text { Ackermann et } \\
\text { al. (1999) }\end{array}$ & $\begin{array}{l}\text { 1- Analyze HF performance with regard to its } \\
\text { risk. 2- Comparing HFs' performance with } \\
\text { MFs and market indices }\end{array}$ & $\begin{array}{l}\text { Sharpe ratio, standard } \\
\text { deviation }\end{array}$ & $\begin{array}{l}\text { HFs offer higher Sharpe ratio than MFs but higher risk. } \\
\text { HFs do not always achieve higher Sharpe ratio } \\
\text { compared to market indices. }\end{array}$ & $\begin{array}{l}\text { MAR and } \\
\text { HFR }\end{array}$ & 906 & 1988- 1995 \\
\hline Lo (2002) & $\begin{array}{l}\text { The effect of serial correlation in monthly } \\
\text { returns on Sharpe ratio }\end{array}$ & Sharpe ratio & $\begin{array}{l}\text { An upward bias in Sharpe ratio is detected due to the } \\
\text { serial correlation }\end{array}$ & $\begin{array}{l}\text { Not } \\
\text { provided }\end{array}$ & Not provided & Not provided \\
\hline \multirow{3}{*}{$\begin{array}{l}\text { Liang and Park } \\
\text { (2007) }\end{array}$} & \multirow{3}{*}{$\begin{array}{l}\text { Analyze the risk-return trade-off in the HF } \\
\text { industry (Comparison between SD, VaR, ES, } \\
\text { and TR with SD) }\end{array}$} & \multirow{3}{*}{$\begin{array}{l}\text { Fama-French (1992) } \\
\text { methodology }\end{array}$} & $\begin{array}{l}\text { 1- Strongly suggest that skewness and kurtosis should } \\
\text { not be ignored when analyzing HF risk }\end{array}$ & \multirow{3}{*}{ TASS } & \multirow{3}{*}{$\begin{array}{l}1101 \text { Live and } \\
429 \text { Defunct }\end{array}$} & \multirow{3}{*}{$\begin{array}{l}\text { Jan. } 1994- \\
\text { Dec. } 2004\end{array}$} \\
\hline & & & $\begin{array}{l}\text { 2- HFs with high expected shortfall (ES) outperformed } \\
\text { those with low (ES) by an annual return difference } \\
\text { margin of } 7 \%\end{array}$ & & & \\
\hline & & & $\begin{array}{l}\text { 3- Expected shortfall (ES) is superior to } \mathrm{VaR} \text { as a risk } \\
\text { measure. }\end{array}$ & & & \\
\hline \multirow{2}{*}{$\begin{array}{l}\text { Kumar et al. } \\
(2010)\end{array}$} & \multirow{2}{*}{$\begin{array}{l}\text { Capture the performance of HFs using } \\
\text { multiple risk-return measures at the same time }\end{array}$} & \multirow{2}{*}{$\begin{array}{l}\text { Slack-Based Data Envelopment } \\
\text { Analysis (DEA) }\end{array}$} & $\begin{array}{l}\text { 1- The correlation between ranking of hedge fund } \\
\text { strategies based on Sharpe ratio and DEA model is } \\
\text { very low }\end{array}$ & \multirow{2}{*}{ Bloomberg } & \multirow{2}{*}{4730} & \multirow{2}{*}{ 1995- 2007} \\
\hline & & & $\begin{array}{l}\text { 2- A significant correlation between rankings obtained } \\
\text { when implementing different set of input/output } \\
\text { measures }\end{array}$ & & & \\
\hline
\end{tabular}


Theoretically: 1- Validity of DEA as an alternative

selection tool for HFs. 2- DEA as a complementary tool

Gregoriou et al. Evaluate the performance of HF

(2005) classifications
Slack-Based Data Envelopment

Analysis (DEA)

to other risk-adjusted measures

ZCM $\quad 614$ for 1 st $\quad 1997-2001$

The results provide empirically validation that even

and 2 nd

when using non-normal returns in risk-return

periods

framework, DEA provides reliable results

Study the suitability of DEA method for HF

performance measurement

Eling (2006)

Pavide

Provide rules for the selection of inputs and

outputs when implementing DEA
Not able to determine whether DEA is a better

measurement tool than others such as Sharpe ratio

Slack-Based Data Envelopment Analysis (DEA)

DEA provides additional information about funds' risk

and returns characteristics

CISDM $\quad 30 \quad$ Jan. 1996-


Table 6- The main articles investigating the systemic risk from special HF activities

\begin{tabular}{|c|c|c|c|c|c|c|}
\hline Name & Objective & Modelling/Framework & Findings & Database & Sample & Period \\
\hline \multirow{4}{*}{$\begin{array}{l}\text { Eichengreen \& } \\
\text { Mathieson } \\
\text { (1998) }\end{array}$} & \multicolumn{3}{|c|}{$\begin{array}{l}\text { In general, they study HFs activities and investigating their policy implications for financial markets. Therefore, they established } \\
\text { three scenarios: }\end{array}$} & \multirow{4}{*}{ Interviews } & \multirow{4}{*}{ NA } & \multirow{4}{*}{1998} \\
\hline & $\begin{array}{l}\text { 1- The effect of leverage } \\
\text { usage by individual or } \\
\text { group of hedge funds on } \\
\text { the market }\end{array}$ & \multirow{3}{*}{$\begin{array}{l}\text { Principle Component Analysis/ } \\
\text { Style Divergence, Style } \\
\text { convergence, Correlation analysis }\end{array}$} & $\begin{array}{l}\text { 1- Support the argument that hedge funds are not able to } \\
\text { influence or manipulate market stability }\end{array}$ & & & \\
\hline & $\begin{array}{l}\text { 2- The existence of } \\
\text { herding behaviour by other } \\
\text { large investors that might } \\
\text { impose pressure on the } \\
\text { market }\end{array}$ & & $\begin{array}{l}\text { 2- Reject the presence of herding behaviour since HF } \\
\text { managers believe in following unique strategies that } \\
\text { should not be disclosed to the market }\end{array}$ & & & \\
\hline & $\begin{array}{l}\text { 3- The use of positive } \\
\text { feedback trading rules by } \\
\text { hedge funds }\end{array}$ & & $\begin{array}{l}\text { 3- No sign of positive feedback trading strategies being } \\
\text { used by hedge funds }\end{array}$ & & & \\
\hline \multirow{3}{*}{$\begin{array}{l}\text { Fung and Hsieh } \\
(2000)\end{array}$} & \multirow{3}{*}{$\begin{array}{l}\text { 1- Study HFs' impact on } \\
\text { market stability }\end{array}$} & \multirow{3}{*}{$\begin{array}{l}\text { Principle Component Analysis/ } \\
\text { Style Divergence, Style } \\
\text { convergence, Correlation analysis }\end{array}$} & $\begin{array}{l}\text { 1- For some market events such as the European bond } \\
\text { market rally in } 1993 \mathrm{HFs} \text { activities impacted the market. } \\
\text { Whereas, for some other events, such as the Asian } \\
\text { Currency Crisis of 1997, HFs did not have any influence } \\
\text { on the market }\end{array}$ & \multirow{3}{*}{$\begin{array}{l}\text { TASS, Investment } \\
\text { fund newsletter, MAR, } \\
\text { Micropal and Nelson, } \\
\text { and private sources }\end{array}$} & \multirow{3}{*}{27} & \multirow{3}{*}{$\begin{array}{l}\text { Oct. } 1987- \\
1997\end{array}$} \\
\hline & & & $\begin{array}{l}\text { 2- HFs do not act as a single group due to the existence of } \\
\text { different styles with unrelated trades }\end{array}$ & & & \\
\hline & & & $\begin{array}{l}\text { 3- No evidence that positive feedback trading is used by } \\
\text { HFs and no evidence of herding behaviour in the HF } \\
\text { industry }\end{array}$ & & & \\
\hline $\begin{array}{l}\text { Chany et al. } \\
(2005)\end{array}$ & $\begin{array}{l}\text { Attempt to quantify the } \\
\text { potential impact of HFs on } \\
\text { systemic risk using new } \\
\text { risk measures on returns }\end{array}$ & Regime switching models & $\begin{array}{l}\text { Systemic risk is likely to increase in the future while } \\
\text { expected return will face a period of downward trend }\end{array}$ & $\begin{array}{l}\text { CSFB/Tremont and } \\
\text { TASS }\end{array}$ & 1837 & $\begin{array}{l}\text { Jan. } 1999- \\
\text { Dec. } 2003\end{array}$ \\
\hline
\end{tabular}




\begin{tabular}{|c|c|c|c|c|c|c|}
\hline Name & Objective & Modelling/Framework & Findings & Database & Sample & Period \\
\hline \multirow{3}{*}{ Lo (2001) } & \multirow{3}{*}{$\begin{array}{l}\text { Provides an introduction and } \\
\text { overview of the risk management } \\
\text { practices of the hedge fund industry }\end{array}$} & \multirow{3}{*}{ NA } & $\begin{array}{l}\text { 1- Traditional risk management tools such as mean-variance } \\
\text { analysis, beta, and Value-at-Risk do not capture much of the } \\
\text { risk exposures of HF investment }\end{array}$ & \multirow{3}{*}{$\begin{array}{l}\text { HF indices } \\
\text { and S\&P } 500 \\
\text { index }\end{array}$} & \multirow{3}{*}{ NA } & \multirow{3}{*}{$\begin{array}{l}\text { Jan. } 1996 \\
\text { Nov. } 1999\end{array}$} \\
\hline & & & $\begin{array}{l}\text { 2- Study different aspects of risk management for HFs such as } \\
\text { dynamic risk analytic, survivorship bias, nonlinearity, and } \\
\text { liquidity. }\end{array}$ & & & \\
\hline & & & $\begin{array}{l}\text { 3- A suggestion that it is necessary to design a new set of tools } \\
\text { creating risk transparency without compromising the proprietary } \\
\text { nature of HF investment strategies }\end{array}$ & & & \\
\hline \multirow{2}{*}{$\begin{array}{l}\text { Alexander and } \\
\text { Baptista (2002) }\end{array}$} & $\begin{array}{l}\text { 1- Analyze the economic impact } \\
\text { arising from regulators and managers } \\
\text { imposing Value at Risk in the } \\
\text { portfolio selection problem of a fund } \\
\text { manager }\end{array}$ & VaR Framework & $\begin{array}{l}\text { 1- Using } \mathrm{VaR} \text { as a tool of risk management might create major } \\
\text { problems }\end{array}$ & \multirow{2}{*}{ NA } & \multirow{2}{*}{ NA } & \multirow{2}{*}{ NA } \\
\hline & $\begin{array}{l}\text { 2- Compare the results with those } \\
\text { arising from imposing Conditional } \\
\text { Expected Loss (CEL) also known as } \\
\text { Conditional-VaR (C-VaR) }\end{array}$ & Mean-VaR Framework & $\begin{array}{l}\text { 2-The } \mathrm{C}-\mathrm{VaR} \text { constraints are tighter than those of } \mathrm{VaR} \text { which } \\
\text { makes } \mathrm{C}-\mathrm{VaR} \text { a more effective tool to control aggressive risk- } \\
\text { averse fund managers. }\end{array}$ & & & \\
\hline \multirow{3}{*}{$\begin{array}{l}\text { Agarwal and } \\
\text { Naik (2004) }\end{array}$} & $\begin{array}{l}\text { 1- Examine the non-linear option-like } \\
\text { exposure of hedge fund returns to } \\
\text { standard asset classes }\end{array}$ & Option-based model & $\begin{array}{l}\text { 1- A wide range of HF strategies exhibit returns similar to those } \\
\text { from writing a put option on the equity index, therefore, bearing } \\
\text { a significant left-tail risk. }\end{array}$ & \multirow{3}{*}{$\begin{array}{l}\text { HFR and } \\
\text { CSFB/Tremon } \\
\text { t index }\end{array}$} & \multirow{3}{*}{ NA } & \multirow{3}{*}{$\begin{array}{l}\text { Jan. } 1990 \\
\text { June } 2000\end{array}$} \\
\hline & \multirow{2}{*}{$\begin{array}{l}\text { 2- Compare and contrast the tail } \\
\text { losses of portfolios constructed using } \\
\text { mean-variance framework and mean- } \\
\text { conditional value-at-risk framework. }\end{array}$} & \multirow{2}{*}{$\begin{array}{l}\text { Portfolio construction } \\
\text { Framework }\end{array}$} & $\begin{array}{l}\text { 2- The mean-variance framework underestimates tail losses to } \\
\text { some extent especially for a portfolio with low volatility. }\end{array}$ & & & \\
\hline & & & $\begin{array}{l}\text { 3- Using the mean-conditional value at risk (M-CVaR) can be } \\
\text { advantageous in the construction of HF portfolios since it } \\
\text { explicitly accounts for the negative tail risk. }\end{array}$ & & & \\
\hline
\end{tabular}


1- The majority of HFs are adequately capitalized, with only a small proportion (3.7\%) of live funds being under-capitalized.

Investigate the risk characteristics an capital adequacy using Value-at-Risk casital adequacy measures
Extreme Value Theory /

$\mathrm{VaR}$, and Monte Carlo

simulation and other tests

as a robustness verification
2- VaR-based measures are superior to traditional risk measures

like standard deviation of returns and leverage ratios, in

capturing hedge fund risk

3- VaR is effective in capturing the underlying risk trends in $\mathrm{H}$ returns that lead to a fund's death. This is evidenced by a

significant upward trend in VaR for dead funds while no such

trend is observed for live funds. Bali et al. Empirically investigate the existence (2007) between VaR and HF returns
Univariate and bivariate portfolio level analyses an fund level regression
1- The existence of a positive relationship indicating that live fund with high VaR outperform those with low VaR by an annual return difference of $9 \%$

2- A reverse risk-profile for defunct funds that have a negative

$\begin{array}{lll}\text { HFR and } & 3080 & \text { Jan. } 1995- \\ \text { TASS } & & \text { Dec. 2003 }\end{array}$
relationship indicating that the higher the VaR the lower the expected return.
1- The critical decision in selecting a Value-at-Risk model for HFs is the distributional assumption

2- The t-student and, especially the Cornish-Fisher expansion, distributional assumptions have the best performance Indices

(CSFB/Tremo $2600 \quad$ Jec. 2003

Monteiro (2004) Evaluates the performance of VaR framework nt)

3- EWMA and E-GARCH models have the best volatility

forecast performance for HFs in terms of statistical loss

functions. In contrast for traditional assets, the best volatility

model is the simple sample variance. 
Analyze the Long-Term Capital

management's strategies (LTCM) in

terms of the fund's VaR and the

amount of capital necessary to suppo

its risk profile
Points out risk management lessons learnt from the LTCM

crisis: 1st, the danger of optimization biases, which created huge

leverage and extreme sensitivity to instability in the

NA

management models ignoring asset and funding liquidity. 3rd,

the implications of using convergence-arbitrage strategies

\begin{tabular}{|c|c|c|c|c|c|c|}
\hline \multirow{3}{*}{$\begin{array}{l}\text { Cassar and } \\
\text { Gerakos (2013) }\end{array}$} & $\begin{array}{l}\text { 1- Empirically investigate the } \\
\text { determinates and effectiveness of } \\
\text { methods that HFs use to manage } \\
\text { portfolio risk }\end{array}$ & \multirow{3}{*}{$\begin{array}{l}\text { Cross-sectional regression } \\
\text { model }\end{array}$} & \multirow{3}{*}{$\begin{array}{l}\text { Models of portfolio risk (VaR, Scenario Analysis, and Stress } \\
\text { Testing) assist managers in reducing exposures to systematic } \\
\text { and downside risks and increases the accuracy of manager's } \\
\text { expectations. }\end{array}$} & \multirow{3}{*}{$\begin{array}{l}\text { HF due } \\
\text { diligence } \\
\text { Group }\end{array}$} & \multirow{3}{*}{427} & \multirow{3}{*}{$2003-2007$} \\
\hline & $\begin{array}{l}\text { 2- The effect of using formal portfolio } \\
\text { risk models on HF returns }\end{array}$ & & & & & \\
\hline & $\begin{array}{l}\text { 3- The effect of using formal portfolio } \\
\text { risk models on the accuracy of } \\
\text { managers' expectations }\end{array}$ & & & & & \\
\hline
\end{tabular}

